\title{
Evaluation of Risk Factors of HCV infection in Lahore, (Pakistan)
}

\author{
Rao Muhammad ljaz \\ Institute of Statistics \\ University of the Punjab \\ Q.A. Campus, Lahore \\ Ahmad Saeed Akhter \\ Institute of Statistics \\ University of the Punjab \\ Q.A. Campus, Lahore
}

\begin{abstract}
Hepatitis C Virus (HCV) infection is rapidly growing disease in world in general and in Pakistan in particular. In Pakistan more than 10 million persons have $\mathrm{HCV}+\mathrm{ve}$ signs. Risk factors for this fatal disease included main, historic and demographic factors. Some researchers segregated few independent factors but other, include them in the category of depends. We have collected the data for Lahore (Pakistan) and analyzed this data by considering the aforesaid factors. Some results of this research do not match with the existing theories. We recommended that interaction effects of associated factors should also be considered in evaluation.
\end{abstract}

Keywords: chi-square, correlation, adjusted odds ratio.

\section{Introduction}

Human beings are at risk due to infinite number of diseases some of which have been diagnosed by researchers and remainders are, still an alarming siren for them. Some diseases have definite source for their occurrence, some have been diagnosed to possess possible causes but a large number of diseases with respect to their causes, in medical science, are still unidentified, Hepatitis $C$ Virus $(\mathrm{HCV})$ infection is one of them. Spread of Hepatitis C Virus (HCV) requires bloodto-blood contact. The two most common ways that hepatitis $C$ is spread, in Pakistan, are by injection and blood transfusion. Hepatitis $C$ absolutely cannot be spread by casual contact. It can potentially be spread within families, by sharing razors, toothbrush, nail cutter etc or on barber's shops. HCV is not easily transmitted through sex because the hepatitis $C$ virus is not found in semen or cervical secretions.

$\mathrm{HCV}$ is the major cause of non-A, non-B hepatitis, worldwide that was discovered in 1989 and serological tests for blood screening were developed soon after, (Choo QL, Kuo G, Weiner AJ et al. 1989) and (Kuo G, Choo QL, Alter et al. 1989) have given the detailed study about it. According to (Alter, M.J., et al. 1992 HCV has been the leading cause of chronic viral hepatitis in the United States and about 3.9 million population in that country were infected. Due to its capacity to mutate, no vaccination at the moment can be developed and presence of antibodies against it in body does not confer any resistance against this virus in a concrete way. (Seyed Moayed Alavian et al 2002) discusses that the treatment of hepatitis $\mathrm{C}$ remains a very demanding and yet not quite promising task and this 
fact adds to the importance of prevention of this disease. Controlling the risk factors is one of the best measures of prevention and this has caused the medical world to search for risk factors of this disease through different studies. According to (Stephen A. villano, et al 1997), existing therapies are successful in less than one-third of cases, and no HCV vaccine is available, efforts to reduce $\mathrm{HCV}$ transmission are crucial to reduce the impact of this disease. However, Cirrhosis, Internal bleeding, Altered conscious level, Fluid retention, and Liver cancer. are the complications due to Hepatitis C. Di Bisceglie, et al (1991), Kiysowa, K., (1990), Terrault, N.A. \& T.L. Wright. (1995) and Tong, M.J. (1995) studied the Chronic HCV infection, and found that it is strongly associated with cirrhosis, liver cancer, and end stage diseases requiring transplantation,

According to Seyed Moayed et al (2002) numerous possible risk factors have been evaluated, some of which have been identified, as independent risk factors of HCV infection, like blood transfusion, endoscopies, sexual activities etc. But our analysis for this purpose shows that these factors are significant but not independent, results are shown in the discussion below.

The focus of our study is the risk factors for HCV infection in Pakistan in general and in Lahore in particular. We collected the data with the kind cooperation of gesterntrologists and analyzed it with the help of SPSS, Statistical software. The results of our analysis are given in the following table-1.

\section{Methodology}

In this research we present a study, which is a part of Meta analysis being conducted in teaching hospitals through out the Punjab (Pakistan). Our study consists an Initial analysis on 330 patients (135 cases \& 195 controls), the data was collected from the major hospitals at Lahore. We have used the odds ratios and chi-square statistics for the analysis.

Table-1

\begin{tabular}{|c|c|c|c|c|c|c|c|c|c|c|c|}
\hline \multirow{2}{*}{$\begin{array}{l}\text { Risk } \\
\text { Factors }\end{array}$} & \multirow{2}{*}{$\begin{array}{l}\text { Odds } \\
\text { Ratio }\end{array}$} & \multicolumn{2}{|c|}{$\begin{array}{l}\text { 95\% C-I for } \\
\text { Odds Ratio }\end{array}$} & \multirow{2}{*}{$\begin{array}{l}\text { Chi- } \\
\text { Square }\end{array}$} & \multirow{2}{*}{$\begin{array}{l}\text { P. } \\
\text { Value }\end{array}$} & \multirow[t]{2}{*}{ Risk Factors } & \multirow{2}{*}{$\begin{array}{l}\text { Odds } \\
\text { Ratio }\end{array}$} & \multicolumn{2}{|c|}{$\begin{array}{l}95 \% \text { C-I for } \\
\text { Odds Ratio }\end{array}$} & \multirow{2}{*}{$\begin{array}{l}\text { Chi- } \\
\text { Square }\end{array}$} & \multirow{2}{*}{$\begin{array}{l}\text { P- } \\
\text { Value }\end{array}$} \\
\hline & & LCL & UCL & & & & & LCL & UCL & & \\
\hline $\begin{array}{l}\text { Blood } \\
\text { Transfusion }\end{array}$ & 3.133 & 1.375 & 7.13 & 4.804 & .028 & Fever History & 3.118 & 1.231 & 7.900 & 27.546 & .000 \\
\hline $\begin{array}{l}\text { Injection } \\
\text { History }\end{array}$ & 2.175 & .726 & 6.511 & 17.012 & .000 & $\begin{array}{l}\text { Pruritis } \\
\text { History }\end{array}$ & 2.466 & .930 & 6.539 & 18.926 & .000 \\
\hline $\begin{array}{l}\text { Barber } \\
\text { Shave }\end{array}$ & 3.314 & .846 & 12.977 & 2.68 & .102 & Malina History & 1.061 & .385 & 2.924 & 10.469 & .001 \\
\hline Piercing & 1.721 & .195 & 15.211 & .668 & .407 & $\begin{array}{l}\text { Encaplopathy } \\
\text { History }\end{array}$ & 1.239 & .470 & 3.269 & 11.879 & .001 \\
\hline Needle Pick & .558 & .226 & 1.378 & .121 & .728 & $\begin{array}{l}\text { Haematenesis } \\
\text { History }\end{array}$ & .823 & .271 & 2.500 & 5.692 & .017 \\
\hline $\begin{array}{l}\text { Dental } \\
\text { Surgery }\end{array}$ & .846 & .372 & 1.926 & 3.725 & .054 & Age & 1.035 & 1.003 & 1.068 & 14.913 & .005 \\
\hline $\begin{array}{l}\text { Family } \\
\text { History }\end{array}$ & .763 & .275 & 2.118 & 2.676 & .102 & Gender & 1.062 & .115 & 9.813 & .255 & .614 \\
\hline Surgery & .673 & .295 & 1.537 & 5.302 & .021 & Marital status & .139 & .024 & .788 & 1.277 & .258 \\
\hline Endoscopy & 1.765 & .333 & 9.340 & 3.308 & .086 & Height & .996 & .901 & 1.101 & 1.943 & .584 \\
\hline Heterosexual & .853 & .109 & 6.664 & .358 & .55 & Weight & .999 & .969 & 1.030 & 5.886 & .117 \\
\hline $\begin{array}{l}\text { Jaundice } \\
\text { History }\end{array}$ & 1.291 & .505 & 3.301 & 5.875 & .16 & Location & 2.327 & .993 & 5.449 & 6.429 & .011 \\
\hline
\end{tabular}




\section{Discussion}

Injection history is highly significant factor with smallest P-value (0.000) means that spread of disease through the non-disposable syringe is very common. Blood transfusion and surgery are highly significant factors because their P-value is very small i.e. less than $3 \%$ it means that blood transfusion and surgery play a highly significant role in spread of HCV infection. Dental procedure is a significant factor with P-value less than $6 \%$ and endoscopies are significant with P-value less than $9 \%$ means that dental surgery and endoscopies play a significant role in spread of HCV infection. Barber shave and family history are factors having same P-value $10.2 \%$, we can not ignore the significance of these factors towards killing disease. All the history variables, fever history, pruritis, malena, enceplopathy and haematenesis except history of jaundice are highly significant with very small $P$-value means that a patient with $\mathrm{HCV}$ infection must have a fever frequently, itching on body, black stool, and blood vomiting. A patient of this disease also has jaundice because P-value is not very large. Age is significant with very small $P$-value that means that people of old age are at high risk. Gender is not significant that means male and female are almost equally at risk of this disease. Location is highly significant factor that means people living in rural area are at more risk of this disease than people living in urban areas. Martial status, height and weight are not significant factors.

However, we have arranged the main risk factors including historical and demographic factors by the order of their intensity of significance and the results are shown in the following table- 2 .

Table-2

$\begin{array}{lccccc}\text { Risk Factors } & \begin{array}{c}\text { Odd } \\ \text { Ratios }\end{array} & \begin{array}{c}\text { 95\% C.I for odd Ratios } \\ \text { LCL }\end{array} & \text { UCL } & \text { CHIS } & \text { P-VALUE } \\ \text { Injection History } & 2.175 & 0.726 & 6.511 & 17.012 & 0.000 \\ \text { Fever History } & 3.118 & 1.231 & 7.900 & 27.546 & 0.000 \\ \text { Pruritis History } & 2.466 & 0.93 & 6.539 & 18.926 & 0.000 \\ \text { Malena History } & 1.061 & 0.385 & 2.924 & 10.469 & 0.001 \\ \text { Encephlopathy } & 1.239 & 0.47 & 3.269 & 11.879 & 0.001 \\ \text { Age } & 1.035 & 1.003 & 1.068 & 14.913 & 0.005 \\ \text { Location } & 2.327 & 0.993 & 5.449 & 6.429 & 0.011 \\ \text { Haematenesis } & 0.823 & 0.271 & 2.500 & 5.692 & 0.017 \\ \text { Surgery } & 0.673 & 0.295 & 1.537 & 5.302 & 0.021 \\ \text { Blood Transfusion } & 3.133 & 1.375 & 7.134 & 4.804 & 0.028 \\ \text { Dental surgery } & 0.846 & 0.372 & 1.926 & 3.725 & 0.054 \\ \text { Endoscopy } & 1.765 & 0.333 & 9.340 & 3.308 & 0.086 \\ \text { Barber Shave } & 3.314 & 0.846 & 12.977 & 2.68 & 0.102 \\ \text { Family History } & 0.763 & 0.275 & 2.118 & 2.676 & 0.102 \\ \text { Weight } & 0.999 & 0.969 & 1.030 & 5.886 & 0.117 \\ \text { Jaundice History } & 1.291 & 0.505 & 3.301 & 5.875 & 0.160 \\ \text { Marital Status } & 0.139 & 0.024 & 0.788 & 1.277 & 0.258 \\ \text { Piercing } & 1.721 & .195 & 15.211 & 0.668 & 0.407 \\ \text { Hetero Sexual } & 0.853 & 0.109 & 6.664 & 0.358 & 0.550 \\ \text { Height } & 0.996 & 0.901 & 1.101 & 1.943 & 0.584 \\ \text { Gender } & 1.062 & 0.115 & 9.813 & 0.255 & 0.614 \\ \text { Needle Prick } & 0.558 & 0.226 & 1.378 & 0.121 & 0.728\end{array}$


Injection, Fever and Pruritis are the most significant factors. Malena, Encephlopathy, age, Location, Haematenesis, surgery and blood transfusion are the next most significant factors by the order of their significance, which are playing a vital role in the spread of HCV infection in Lahore in particular and in Pakistan in general.

\section{Correlations}

** Correlation is significant at the 0.01 level (2-tailed).

* Correlation is significant at the 0.05 level (2-tailed).

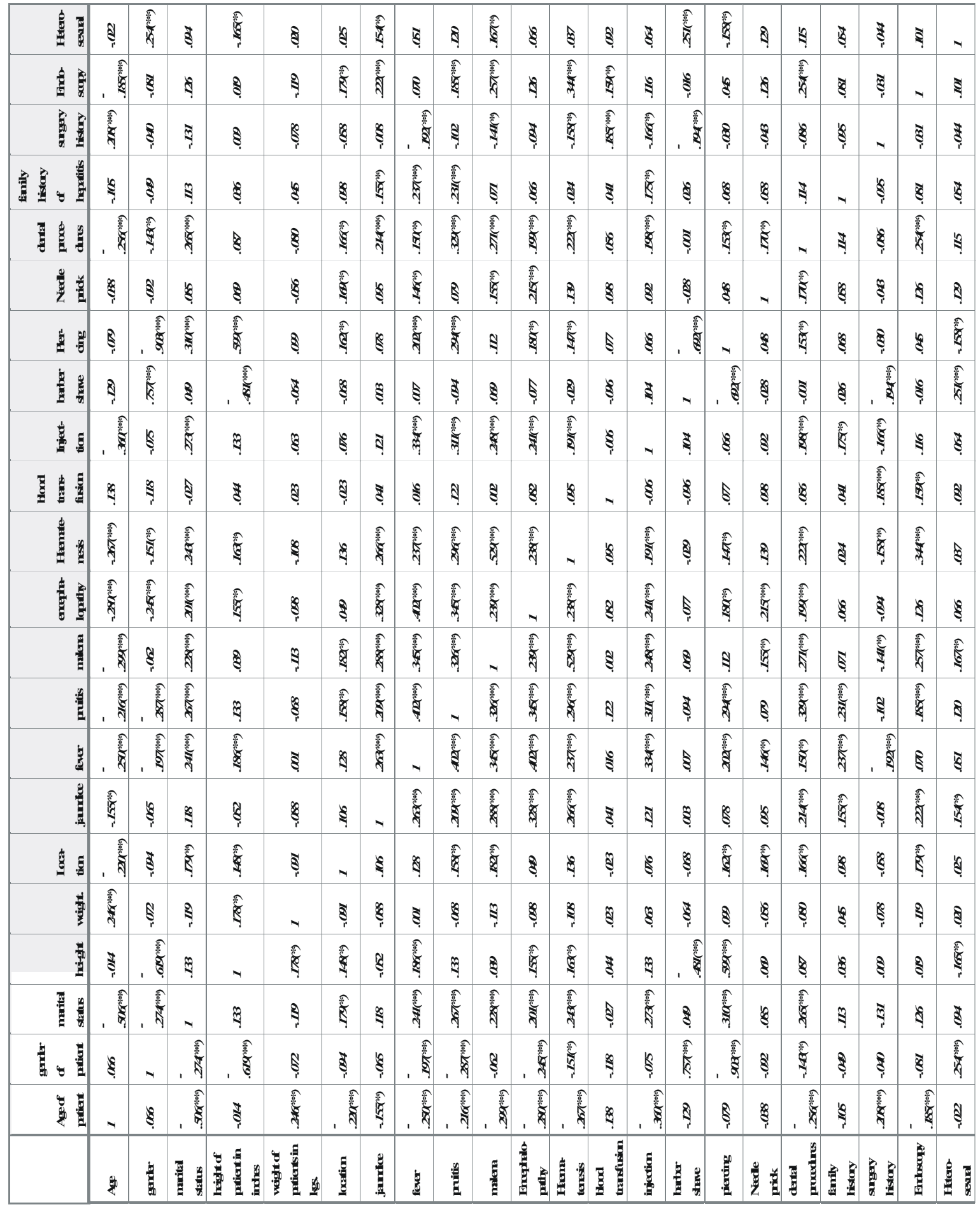


Risk factor Blood Transfusion is correlated with the risk factors Surgery and Endoscopies this means that Surgery and Endoscopies are the main causes of blood transfusion, History of injection is correlated with Dental Procedure, Family History and surgery, and here again surgery is correlated with risk factor named injection. Also in the same comparison we see that injection factor and Barber Shave are correlated with Surgery and Heterosexual, Piercing is correlated with Dental Procedure and injection, Needle Prick is correlated with Dental Procedure and Dental Procedure is correlated with Endoscopies. Main risk factors considered in this paper are all correlated and no independent risk factor is detected. It means their interaction effect may play a significant role in spread of disease.

Jaundice, Fever, Pruritis, Malena, Enceplopathy and Haematenesis are historical factors they are highly correlated with each other means that these are almost present in HCV patients.

When we go through the correlation analysis we found that some correlations are significant, this indicates that interaction effects should also be considered for further analysis, which is under process at the moment.

\section{Acknowledgement}

We are grateful to Dr. Nahid Hamayanue Sheikh, head of department Community medicine, Allama Iqbal Medical College, Lahore (Pakistan) for valuable suggestions while designing the questionnaire.

We are also thankful to Dr. Abdur Rehman, Deputy M.S research, Mayo Hospital, Lahore (Pakistan).

\section{References}

1. Alter, M.J. (1995). Epidemiology of Hepatitis C in the west. Semin. Liver Dis. 15: 92-100.

2. Alter, M.J., H.S. Margolis, K. Krawczynski, F.N. Judson, A. Mares, W.J. Alexander, P.Y. Hu, J.K. Miller, M.A. Gerber, R.E. Sampliner, et al. (1992). N. Engl. J. Med. 327. 1899-1905.

3. Choo QL, Kuo G, Weiner AJ et al. (1989). Isolatio of cDNA clone derived from a blood-born non A, non B viral hepatitis genom. Science 244. 359362.

4. Di Bisceglie, A.M., Z.D. Goodman, K.G. Ishak, J.H. Hoofnagle, J.J. Melpolder, and H.J. Alter. (1991). Long-termclinical and histopathological follow-up of chronic posttransfusion hepatitis. Hepatology 14: 969-974.

5. Kiysowa, K., T. Sodeyama, E. Tanaka, Y. Gibo, K. Yoshizawa, Y. Nakano, S. Furuta, Y.Akahane, K. Nishioka, and R.H. Purcell. (1990). Interrelationship of blood transfusion, non $A$, non $B$ hepatitis and hepatocellular carcinoma: analysis by diction of antibody to hepatitis $\mathrm{C}$ virus. Hepatology 12: 671-675. 
6. Kuo G, Choo QL, Alter et al. (1989). An assay for circulating antibodies to a major etiologic viru of human non $A$, non $B$ viral hepatitis genom. Science 244. 362-364.

7. Seyed Moayed Alavian, Bardia Gholami and Sadegh Masarrat (2002). Hepatitis B and .Hepatitis C infection; Hepatitis C risk factors in Iranian volunteer blood doners. A case control study. Journal of Gastroenterology and Hepatology 17. 1092-1099.

8. Simonetti RG, Camma C, Fiorello F. et al. (1992). Hepatiris C virus infection as a risk factor for hepatocellular carcinoma in patients with cirrhosis. A case-control study. Ann. Intern. Med. 116. 97-102.

9. Stephen A. Villano, David Vlahov, Kenrad E. Nelson, Cynthia M. Lyles, Sylvia Cohn and David L. Thomas. (1997). Incidence and risk factors for hepatitis $\mathrm{C}$ among injection drug users in Baltimore, Maryland. Journal of Clinical Microbiology 35. 3274-3277.

10. Tagger A, Donato F, Ribero ML et al. (1999). Case-control study on hepatitis $C$ virus as a risk factor for hepatocellular carcinoma: the role of HCV genotypes and the synergism with Hepatitis B and alcohol. Brescia HCC Study. Int. J. Cancer 81. 695-699.

11. Terrault, N.A. and T.L. Wright. (1995). Hepatitis C virus in the setting of transplantation. Semin. Liver Dis. 15: 92-100.

12. Tong, M.J., N.S. El-Farra, A.R. Reikes, and R.L. Co. (1995). Clinical outcomes after transfusion-associated hepatitis C. N. Engl. J. Med. 332. 1463-1466. 